\title{
The Research on Service Innovation of Theme Hotel
}

\author{
Su-Ming Huang ${ }^{1, a}$ \\ ${ }^{I}$ Department of Hotel Management, Sanda University, Shanghai, China \\ ${ }^{a}$ smhuang@sandau.edu.cn
}

\begin{abstract}
The innovation of hotel products is based on the product design and development of customers' perceived value. In recent years, the e-sports industry has grown rapidly in China. The differentiation and individualization of hotel's innovative services have been provided enjoy a diverse accommodation experience for hotel customers.

This research mainly focuses on "service innovation", "service quality" and "customer satisfaction" to make in-depth analysis and discussion, and provide a set of innovative standards and customer satisfaction basis for the theme hotel of e-sports services. Using SPSS narrative statistics, factor analysis, reliability and validity analysis, Pearson Productmoment Correlation Analysis, etc.

Empirical research results: (1) The closer the "service innovation" is launched, the more it has a positive impact on "customer satisfaction"; (2) the stability and quality of "service quality" has a positive impact on "customer satisfaction". Moreover, the research makes suggestions for the future development of the e-sports hotel as a reference.
\end{abstract}

Keywords: Service Innovation, Service Quality, Customer Satisfaction, E-Sports Hotel

\section{INTRODUCTION}

\subsection{Background}

On November 18, 2003, the General Administration of Sports formally approved e-sports as an official sports event, the e-sports industry has grown rapidly in China. In 2020, the actual sales revenue of China's e-sports game market will reach 136.557 billion RMB. This is an increase of 41.83 billion RMB from 2018. E-sports games have become the main leisure activities for modern people to relax their minds and relieve stress. The hotel industry upholds the social responsibility of providing rest and diversified accommodation experiences, and the concept of service innovation has emerged spontaneously.

\subsection{Research Objective}

This study will focus on the development of the esports market and the introduction of hotel innovation services as the theme. It is necessary to conduct in-depth analysis and discussion on "service innovation", "service quality" and "customer satisfaction", and hope to provide thematic hoteliers with the development of service innovation strategies.

\subsection{Limitations and suggestions for future studies}

As funding for research and time constraints, it could not comprehensive for customers of e-sports hotels in China.

Follow-up related researchers can include other intermediary variables or interference changes in the conceptual framework of this research, which should be more complete and of academic value.

\section{LITERATURE REVIEW}

\subsection{Current development status of e-sports hotels}

The roots of theme hotels come from the mature market environment and consumer objects, the arrival experiencing economic era and the needs of the development of cultural industries [1]. In recent years, as e-sports has been officially included in the National Sports General Administration as a sports project. "Esports hotel" is a cross-border derivative of hotels. Compared with traditional hotels, it is more entertaining and social, and has gradually become a new entertainment and leisure place. 


\subsection{Innovative services}

Betz (1987) was the first to put forward the concept of service innovation [2]. Service innovation refers to the improvement of services and the diversified needs of customers in response to different needs of customers, thereby increasing the value of the company's products or services [3]. Therefore, service innovation is mainly based on new ideas, new goals and strategies, new innovative implementation methods, new service innovation models, and cross-departmental innovation integration [4]. That is to say, the organization provides consumers through the process of service innovation and different service experience from the past can achieve the meaning of service innovation.

Service innovation is based on novel and different service concepts or service delivery processes through novel or improve problem-solving methods and deliver added value to customers

\subsection{Service quality}

Parasuraman, Zeithaml \& Berry (1985) put forward the gap between the customer's expectation of service and the perception after actual contact with the service. Service quality is not only a measure of its service results, it must also include the process and methods of service providers providing services, etc., and evaluate the quality of service through the gap between service expectations and customer perception service levels [5].

Therefore, the quality of service is closely related to the performance and attitude of service personnel. Improving service quality and service innovation can create extremely high value for customers and themselves [6].

\subsection{Customer satisfaction}

Customer satisfaction is the customer's evaluation of a particular transaction, reflecting the degree of customer expectations [7]. The customer satisfaction variable in this study is measured by consumers of e-sports hotels based on their consumption experience

The core concepts of customer satisfaction and service quality both originated from the "ExpectationDisconfirmation". At present, "service quality" is used as the theoretical basis to conduct research on the subject of "customer satisfaction" in academia. Discussion, this argument is verified from the "PZB Service Quality Model" of Parasuraman et al. Customer satisfaction is a comprehensive evaluation of physical products and intangible services [8]. They believe that service quality only focus on a single-sided measurement, while customer satisfaction is a multi-dimensional measurement. Therefore, the scope of customer satisfaction measurement includes: service quality, product quality, contextual factors, personal factors and price factors.

Customer satisfaction has been valued by understanding the degree of customer satisfaction with products or services, it can be used as a basis for companies to develop products or make improvement.

\section{RESEARCH DESIGN}

\subsection{Research framework}

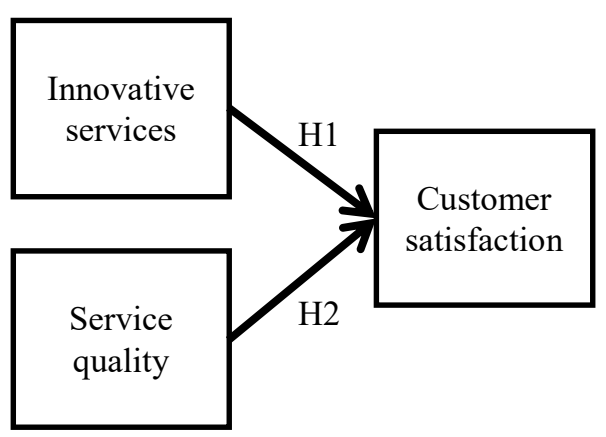

Fig.1 The proposed model of the research

\subsection{Hypothesis}

The hypotheses of this research are as follows:

"Service Innovation" and "Customer Satisfaction": Because of the improvement of income and living standards, consumers' expectations for various innovative products or service innovations launched by hotels are also constantly increasing. Therefore, the esports hotels could be recognized and get higher Customer Satisfaction by providing perfect service innovations or innovative products that exceed customer expectations

Hypothesis 1: "Service Innovation" has a positive impact on "Customer Satisfaction".

"Service Quality" and "Customer Satisfaction": Customer satisfaction is a set of physical products and intangible services. In the overall evaluation, service quality only focus on single-faceted measurement, while customer satisfaction is a multi-faceted measurement. The measurement range includes: service quality, product quality, contextual factors, personal factors, and price factors. Therefore, this study concludes that service quality is the basis of customer satisfaction.

Hypothesis 2: "Service Quality" has a positive impact on "Customer Satisfaction".

\subsection{Constructing the questionnaire and sampling}

The content of this research questionnaire includes four parts: basic information, service innovation, service quality and customer satisfaction. 
This research is based on an online questionnaire survey, and the research objects are mainly consumers with experience staying in 5F.NET+ Hotel in Guizhou. There are 246 valid questionnaires in this study.

\subsection{Data analysis and processing methods}

The SPSS statistical methods used in this study include: (1) Descriptive Statistics. (2) Factor Analysis (3) Reliability \& Validity Analysis (4) Pearson Productmoment Correlation Analysis.

\section{EMPIRICAL ANALYSIS}

\subsection{Descriptive Statistics}

The results of the study of subjects showed that there are more men than women, with men accounting for $52.4 \%$ and women accounting for $45.7 \%$. In terms of education level, universities accounted for the highest percentage $(59.6 \%$ ), with a total of $16.1 \%$ of technical secondary school or above, which shows that all test subjects in this study have a certain level of education.

The subjects in this study accounted for $56.4 \%$ of the 21-30 years old, indicating that the majority of the esports hotels stayed in this study were young people. The top three factors for consumption are: accommodation and use of in-room software $72 \%$, good service quality $10 \%$, and brand preference $2 \%$. Most of the subjects prefer to get lottery coupons for $27 \%$ as promotional activities, followed by online celebrity live broadcast masters serving as the one-day store manager for $21 \%$, and membership-based birthday gifts for $24 \%$. E-sports competitions held in the e-sport hotel for $14 \%$.

\subsection{Reliability analysis}

The research results show that the Cronbach's $\alpha$ value the service innovation item is .863; the Cronbach's $\alpha$ value when the service quality item is .935 ; the Cronbach's $\alpha$ value when the service quality customer satisfaction item is deleted is .935; the overall reliability item The value of Cronbach's $\alpha$ at the time of deletion was .912; the value of Cronbach's $\alpha$ at the time of deletion was $>0.70$, which is a high degree of confidence.

Table1. Reliability analysis

\begin{tabular}{|c|c|c|}
\hline & Cronbach's & N of Items \\
\hline Innovative services & 0.863 & 7 \\
\hline Service quality & 0.935 & 6 \\
\hline Customer satisfaction & 0.935 & 5 \\
\hline Overall reliability & 0.912 & 3 \\
\hline
\end{tabular}

\subsection{Factor analysis}

Principal component analysis and the maximum variation method of the orthogonal axis were used for the axis to extract the variables with characteristic values greater than 1, and the sampling appropriateness KMO (Kaiser-Meyer-Olkin) value reached 0.7, and the Bartlett test reached a significant level. The results showed: The analysis of the factors of service innovation, service quality and satisfaction meets the requirements of adaptability.

\subsection{Correlation analysis}

The results of Pearson product-difference correlation analysis showed that service innovation and service quality have a significant positive correlation $(r=0.75$, $\mathrm{p}<0.001)$; service innovation and customer satisfaction have a significant positive correlation $(r=0.78, p<0.001)$; Service quality and customer satisfaction have a significant positive correlation $(\mathrm{r}=0.91, \mathrm{p}<0.001)$, showing a significant positive correlation between the three. The correlation coefficients are between 0.754 and $0.911(\mathrm{p}<0.001)$, indicating that the higher the respondents' satisfaction with service innovation, the more positive their customer satisfaction; similarly, the results also show the respondents' satisfaction with service quality The higher the customer satisfaction, the more positive it is.

\section{CONCLUSION}

The entire business activities of an enterprise should analysis rigorously the needs of consumers from the perspective of customers. In order to respond to the diversified needs of consumers and the fierce competition in the hotel market, e-sports hotels must integrate "service innovation" into the corporate culture and enhance their core competitiveness.

\subsection{Conclusion for the research}

1."Service Innovation" has a positive impact on "Customer Satisfaction"

Based on the results and analysis, E-sport hotels should explore how product innovation can improve consumer satisfaction from the perspective of consumers, and use novel products to meet the core needs of consumers. This research has learned that new sales models can improve customer satisfaction.

2."Service Quality" has a positive impact on "Customer Satisfaction"

On the whole, it can be inferred that there is a significant positive relationship between service quality and customer satisfaction. Therefore, the enhancement of service quality in e-sports hotels does help increase customer satisfaction. 
Table2. KMO-Bartlett test analysis

\begin{tabular}{|c|c|c|c|c|}
\hline & & \multicolumn{3}{|c|}{ Bartlett Test } \\
\hline Name of factor & $\mathrm{KMO}$ & $\begin{array}{l}\text { Approximate chi-square } \\
\text { value }\end{array}$ & df & Significant value \\
\hline Innovative services & .842 & 379.981 & 27 & .000 \\
\hline Service quality & .873 & 618.752 & 20 & .000 \\
\hline Customer satisfaction & .901 & 511.891 & 14 & .000 \\
\hline
\end{tabular}

Table3. Innovative services/ Service quality /Customer satisfaction Pearson analysis

\begin{tabular}{|l|c|c|c|}
\hline & Innovative services & Service quality & Customer satisfaction \\
\hline Innovative services & 1 & 0.754 & 0.783 \\
\hline Service quality & 0.754 & 1 & 0.911 \\
\hline Customer satisfaction & 0.783 & 0.911 & 1 \\
\hline
\end{tabular}

**When the significance level is 0.001 (two-tailed), the correlation is significant

\subsection{Recommendations}

1. Space diversification: In addition to guest rooms with distinctive themes and outstanding personalities, space planning should be directed towards social experiences such as diversified leisure, competitions, gourmet dining, etc.

2. Exquisite details and refinement: Star-rated smart complex hotel is the future trend. As an e-sports themed hotel, in addition to comfort, safety such as sound insulation and fire prevention are more important.

3. Advanced sensory enjoyment: E-sports hotels have entered a high-end and boutique level, and the hardware configuration must naturally be high-precision equipment. Regardless of whether the plane experience or the VR three-dimensional sensory enjoyment, it must be a core element in the design of an e-sports hotel. For example: Equipped with ROG player national gaming suit.
4. Space theming: integrate the characters, costumes, equipment, and scenes of e-sports games into the design of the themed e-sports hotel, and set up themed spaces with different game elements to meet the atmosphere experience of e-sports game lovers.

5. Professionalization of personnel: The quality of service depends on the delivery of personnel services, and the training of professionalism of service personnel is the key to the differentiation of hotel services.

\section{REFERENCES}

[1] Wang Chong., Lijiang establishes the theme hotel development strategy to discuss the regional economy, 2017.

[2] Betz, F,. Managing Technology-Competing through New Ventures, Innovation, and Corporate Research, N.J.: Prentice-Hall., 1987. 
[3] Vang, J., \& Zellner, C. Introduction: Innovation in Services. Industry \& Innovation, 12(2), 2005, pp.147-152

[4] Spath, D., \& Fähnrich, K.-P. Advances in Services Innovations: Springer, 2007.

[5] Parasuraman, A., Zeithaml, V. A., \& Berry, L. L. A conceptual model of service quality and its implications for future research. Journal of marketing, 49(4), 1985, pp.41-50. DOI: $10.2307 / 1251430$

[6] Berry, L. L., Bolton, R. N., Bridges, C. H., Meyer, J., Parasuraman, A., \& Seiders, K. Opportunities for Innovation in the Delivery of Interactive Retail Services. Journal of Interactive Marketing, 24(2), 2010, pp.155-167.

[7] Oliver, R. L. Measurement and Evaluation of Satisfaction Processes in Retail Settings. Journal of Retailing, 1981.

[8] Zeithaml, V., \& Bitner, M. Services Marketing: Integrating Customer Focus Across the Firm. Boston: McGraw-Hill, 2000. 